University of Nebraska - Lincoln

DigitalCommons@University of Nebraska - Lincoln

Faculty Publications -- Department of English

English, Department of

2009

Transnational Community in Demetria Martínez's Mother Tongue

Ariana Vigil

University of Nebraska - Lincoln, avigil2@unl.edu

Follow this and additional works at: https://digitalcommons.unl.edu/englishfacpubs

Part of the English Language and Literature Commons

Vigil, Ariana, "Transnational Community in Demetria Martínez's Mother Tongue" (2009). Faculty Publications -- Department of English. 83.

https://digitalcommons.unl.edu/englishfacpubs/83

This Article is brought to you for free and open access by the English, Department of at DigitalCommons@University of Nebraska - Lincoln. It has been accepted for inclusion in Faculty Publications -- Department of English by an authorized administrator of DigitalCommons@University of Nebraska - Lincoln. 
Published in Meridians: Feminism, Race, Transnationalism 10:1 (2009), pp. 54-76. Copyright (C) 2010 by Smith College; published by Indiana University Press. Used by permission. "No part of this article may be reproduced, stored in a retrieval system, transmitted, or distributed, in any form, by any means, electronic, mechanical, photographic, or otherwise, without the prior permission of Indiana University Press. For educational re-use, please contact the Copyright Clearance Center (508-744-3350). For all other permissions, please visit Indiana University Press' permissions page."

\title{
Transnational Community in Demetria Martínez's Mother Tongue
}

\author{
Ariana Vigil
}

\begin{abstract}
Relying on feminist theory concerning difference, identity, gender, and solidarity, "Transnational Community in Demetria Martínez's Mother Tongue" reads Martínez's 1994 novel through a transnational feminist lens. I point out that Mother Tongue complicates identification with the other and resists the impulse by characters to elide national, racial, and sexual difference. However, the articulation of community identities and the portrayal of characters as members of both oppressed communities and communities in resistance offers a new and provocative way to understand how individuals interact with identity and attend to important differences while nonetheless working for global change. The resulting analysis contributes to literary scholarship that seeks to understand how characters, authors, critics, and activists create and articulate transnational identities, an analysis particularly relevant given the history of intervention of the U.S. in El Salvador and the recent historic presidential elections in both nations.
\end{abstract}

$$
\ddagger \ddagger \ddagger \ddagger
$$

But my contention here is that the US crimes in the same period have only been superficially recorded, let alone documented, let alone acknowledged, let alone recognised as crimes at all. I believe this must be addressed and that the truth has considerable bearing on where the world stands now. (Pinter 2005)

On March 15, 2009 Salvadorans made history by electing the first leftist government in the country's history. The long history of U.S. inter- 
vention in El Salvador, particularly U.S. support for El Salvador's repressive governments and corrupt military during the civil war (1980-1992), led one Salvadoran-American journalist to call the victory of Mauricio Funes "the defeat of [Reagan], nothing less" (Lovato 2009). ${ }^{1}$ Although President-elect Funes and his FMLN party join a seemingly inspiring slate of elected left-wing leaders throughout Latin America-including Daniel Ortega in Nicaragua, Evo Morales in Bolivia, and Hugo Chavez in Venezuela-the fate of women's rights under the leadership of Funes and his allies remains uncertain. ${ }^{2}$ The once-radical Ortega recently aligned himself with the Catholic Church "to make political plunder of women's bodies" by making therapeutic abortion punishable by up to eight years in prison (Gago 2007, 17-18). Similarly, after the signing of the peace accords in 1992, El Salvador adopted some of the most draconian anti-abortion laws in the world (Hitt 2006). The close relationship between leaders such as Chavez, Ortega, and Funes and the historical role played by the U.S. in Latin American affairs demands that questions of gender and human rights assume a transnational perspective.

In this essay, I apply these considerations to a work set against U.S. involvement in the Salvadoran civil war as I look at the depiction of gendered, transnational communities in Demetria Martínez's 1994 novel Mother Tongue. ${ }^{3}$ I begin by contextualizing my analysis within contemporary feminist theory concerning difference and transnationalism and argue for the importance of including community within these theoretical discussions. After a brief summary of the novel, I turn to the narrative's treatment of community and individual identity. The essay traces the development of Mother Tongue's principal protagonists, María and José Luis, pointing out that Martínez's narrative highlights the multiple misunderstandings that stem from the lovers' unwillingness and inability to see each other in relation to their respective communities. However, the character of Soledad offers an alternative model for recognizing the self's relationship to the community in the service of a progressive political agenda. Self and community are linked to issues of gender, sexuality, and war as I point to how terror meted out by the U.S.-backed Salvadoran armed forces had as its targets not only individuals, but communities of people in resistance. My analysis of the climactic scene of the book highlights María's ability to see José Luis's community for the first time and connects her subsequent activism to this precise moment. María's activism reflects calls by U.S. feminists of color to adopt a trans- 
national perspective. Finally, I consider how the narrative structure of Mother Tongue reflects its community orientation. The end result is an alternative understanding and articulation of how gendered bodies engage in activism to enact a polyvocal form of transnational resistance as well as a new understanding of the potential role of community in identifying, articulating, and engaging in transnational solidarity.

\section{I, who have loved you, / paid for those bullets ${ }^{4}$ : Transnational Literature, Gender, and Difference}

Several scholars note that literature provides an important site from which to explore issues of transnationalism and gender. Constance S. Richards writes: "creating, reading, and writing about literature [provides] an opportunity to explore ourselves and to build alliances with others" (Richards 2000, vii). However, examining gender under a transnational lens, especially in the pursuit of finding "provisionally viable [ways] of conceptualizing and forming communities across cultural borders," requires close attention to questions of similarity and difference (Black 2004, 228). Chandra Mohanty warns that exclusively examining "sexual difference" as a "singular, monolithic notion of patriarchy or male domination leads ... to a similarly reductive and homogenous notion of ... "Third World difference"' (Mohanty 2003,19). Similarly, Richards posits that an ideal formulation of transnational feminism "views the experience of women more broadly than do local feminisms and at the same time recognizes the limitations of a global perspective that homogenizes difference" (Richards 2000, x). In their call for the acknowledgment of difference that encompasses not just gender, but race, nationality, and access to power, Richards and Mohanty approach difference as a relational rather than essential category: that is, a concept of difference that does not name otherness, but one that exposes similarity, dissimilarity, and specificity (Young 1990, 168-73). ${ }^{5}$ In their attempts to avoid the homogenization of difference, both critics acknowledge their status as U.S. academics; Richards suggests that her background as a reader of literature "trained in academic feminism" may predispose her to "an oppositional stance," whereas Mohanty asserts: "I speak as a person situated in the One-Thirds World, but from the space and vision of, and in solidarity with, communities in struggle in the Two-Thirds World" (Richards 2000, 34; Mohanty 2003, 228). 
Although such frank personal admissions are no doubt a part of "[envisioning] a feminist theory and practice" that avoids "obliterating difference," Mohanty's and Richards's own reliance on individual experiences to explain relationships with identities grounded in the histories and current circumstances of groups of people leaves some questions unanswered (Richards 2000, $x$ ). That is, in our quest to understand how characters, authors, critics, academics, and activists engage in transnational work and rhetoric, we must ask: who precisely creates and participates in these theoretical practices?

In her analysis of how feminist theory disrupts hegemonic knowledge institutions, Nelly Richard critiques the individual voice. She writes that when "female subjects and colonized speakers ... stitch together their own vocabularies with stolen (alien) meanings capable of subverting the colonialist dogma of the foundational text's purity and originality," they also engage in a confrontation with "the authority of the Whole as metaphor for universal knowledge" (Richard 2004, 15). To take seriously the suggestions of Richards, Mohanty, and Richard, then, requires that we acknowledge differences owing to class, gender, race, sexuality, ability, and national context (among others), but we do so in a way that thinks beyond the authority of a singular voice, be that the voice of the author, character, or critic.

\section{Mother Tongue}

Mother Tongue tells the story of María, a Chicana from New Mexico, who aids and eventually falls in love with José Luis Alegría, a Salvadoran fleeing his country. ${ }^{6}$ María and José Luis develop a friendship that escalates into an intense and at times painful love affair. Through their relationship, both characters are forced to confront the violence of their pasts - his at the hands of Salvadoran torturers who abducted him and murdered his fiancé, hers at the hands of a sexually abusive neighbor. Their story is told through several different voices including that of their son (also called José Luis), as well as through newspaper articles, diary entries, and poems.

The novel contains four main characters and three narrators. María, the principal narrator, is nineteen years old at the story's beginning. Through her friend Soledad, a fifty-year-old Mexican immigrant, she becomes involved in the sanctuary movement and meets José Luis, 
then twenty-nine years old. ${ }^{7}$ José Luis stays at Soledad's house during the summer of 1982, and the majority of Mother Tongue's narrative centers on this time period. The story unfolds mostly from María's perspective as she, nearing forty, recounts her relationship with José Luis. Through a diary that María translates, readers are also privy to José Luis's thoughts and feelings. José Luis Jr., narrates the fourth and final section of the novel, telling readers of his and María's trip to El Salvador to search for information about his father.

Existing criticism on Mother Tongue has focused primarily on issues of voice, (mis)translation, language, collective memory, and the body; several critics, however, have also noted the novel's treatment of themes of belonging, solidarity, and group identity. ${ }^{8}$ While Kelli Lyon-Johnson writes that María and Soledad write Chicana sanctuary activists into history, suggesting "the power of the Latino/a community in the United States," other scholars note how the narrative undermines naïve notions of community (Lyon-Johnson 2005, 215). Marta Caminero-Santangelo writes: "The main thrust of the narrative of Mother Tongue ... continually ... destabilize[s] the grounds for ... a fantasy of connectedness by emphasizing the ways in which [María's] experience as a Mexican American and José Luis's experiences as a Salvadoran have created fundamentally different subjects" (Caminero-Santangelo 2001, 198). Similarly, Dalia Kandiyoti points out how Maria's interactions with José Luis present her false assumptions concerning the supposed "seamlessness of the Latino-Latin American connection" (Kandiyoti 2004, 422). Indeed, the near continual mistranslations of José Luis on María's part highlight how very far away her experiences as a middle-class, U.S.-born Chicana are from those of her Salvadoran lover. ${ }^{9}$ According to Caminero-Santangelo, the climactic scene of the novel, in which María's abuse at the hands of José Luis triggers her own memories of earlier abuse, functions as an unsuccessful attempt to connect María's experiences to José Luis's, and the result is a "perhaps too easy impulse ... to assert overriding connections, or equations, in the face of difference" (Caminero-Santangelo 2007, 211).

Although Mother Tongue points quite directly to the flaws inherent in generic assumptions of community based on unstable categories such as language, ethnicity, and even personal experience, it does not preclude the possibilities of transnational community. As Jean Wyatt writes, “acknowledging identification's tendency to assimilate dif- 
ference to the same need not preclude the recognition that identification also opens us up to difference" (Wyatt 2004, 169). Rather, in constructing knowledge of self and other as "a field filled with tension ... between the general and the particular, the totalizing and the fragmentary," Mother Tongue creates a concept of "gendered and sexual difference as a transversal axis ... so as to pluralize" difference (Richard 2004, 15-16). María's early perspective concerning her connections to José Luis, while failing to adequately account for difference, serves to point out the very fallible ways in which ideas of community may be constructed, even as her character speaks to the real importance of such connections. The narrative paints a sympathetic portrayal of María's quest for community support and paints such a community-specifically a transnational Latina/o community - as integral to her growth throughout the novel. The result is a renewed understanding of community, one that is based less on essentialist notions (of race, ethnicity, family) and more on "voluntary association[s] of a profoundly committed sort, that is, of solidarity" (Caminero-Santangelo 2007, 209).

The first line of the novel, written from María's perspective, reflects María's individualistic orientation as she mentions José Luis's nation only to distance him from his homeland. María writes: "His nation chewed him up and spat him out like a piñon shell, and when he emerged from an airplane one late afternoon, I knew I would someday make love with him" (Martínez 1994, 3). Neither José Luis's nor María's country is named. Moreover, María turns a conflict that has everything to do with national identity (his and hers), and José Luis's membership in a targeted community, into a purely personal affair. Her reliance on singular personal pronouns - "he," "I" - illustrates how María understands herself and José Luis. Furthermore, María's description of José Luis's face is overdetermined by ethnic and national markers; he possesses "a face with no borders: Tibetan eyelids, Spanish hazel irises, Mayan cheekbones" (Martínez 1994, 3). Seeing José Luis as generically "other" allows María to see him as placeless, to divorce him from specific racial and national histories. Moreover, her idea of José Luis allows María to read his presence in her life as a romantic twist of fate, rather than a move that has everything to do with nations and communities.

In stark contrast to María's self-centered fantasy of romance is Soledad's instructional letter, and just as María invokes only singular pronouns, Soledad relies on plural pronouns to connect her life to the lives 
of her friends and comrades. Her first reference to José Luis is as "our guest," a term that references a larger, albeit paternalistic, group of activists. In addition, Soledad offers a compelling and concrete portrait of the community that makes up "we." She lists others in Albuquerque who will lend their services to José Luis - a barber on $2^{\text {nd }}$ Street, volunteers, doctors, and lawyers (Martínez 1994, 4-5). Only later in her letter does Soledad discuss her personal life, and this too she explains in relationship to a larger cause, as she tells María that her marriage was only for the protection that U.S. citizenship offered an immigrant in need (6). Thus Soledad discusses herself and her personal life only in relationship to a larger community of activists and in support of progressive causes, while young María avoids any mention of specific political or ethnic communities as she attempts to script José Luis into her own personal narrative.

María continues to stress her inability to understand either herself or José Luis in relation to anything or anyone besides each other. Again, in her opening section she writes: "Before his arrival the chaos of my life had no axis about which to spin. Now I had a center" (Martínez 1994, 4). José Luis exists only in relation to María, and she only in relation to him. Later, in a starkly beautiful moment of mistranslation, the lovers share their visions of El Salvador, his based on raw knowledge and hers on fantasies and ignorance: "I said, José Luis, last night I dreamed I was there, I smelled bougainvillea. He said, I dreamed I was there too, mi amor, but it was something about white phosphorous, napalm" (42). María's El Salvador is empty of people, full only of romantic ideas. José Luis's image of El Salvador, in contrast, invokes manufactured weapons, used by one group of people against another. Laura Lomas explains that moments such as these mark the ways in which María fails to recognize difference. María's "self-projection elides José Luis's difference" and illustrates "how easy it is for the North American characters, including the big-hearted María, to consume a sensationalized, romanticized, or demonized version of the Salvadoran or Chicana in their midst" (Lomas 2006, 361). When José Luis gently corrects María's fantastic notion of El Salvador, he resists her consumption of his identity and history, a resistance he continues throughout their relationship.

While María attempts to separate José Luis from his national context, she similarly distances herself from any community-based identity. As Kandiyoti and Debra Castillo point out, María “perceives her- 
self as an inauthentic Latina subject" and expresses "insecurity about her acculturated double identity as Latina and gringa" (Kandiyoti 2004, 432; Castillo 1997, 13). María's anxiety about her Chicana heritage is expressed as a subsequent distancing from this culture. When the novel opens, María lacks any connection to a larger family, network, or community. As Gabriella Favela Gutiérrez y Muhs notes, unlike most Chicana characters in literature, María is almost completely devoid of family or friends (Gutiérrez y Muhs 2004, 135). Her mother died of cancer and her father abandoned the family when she was young. In addition to having no family, María only once mentions friends, who "quit calling" when they heard she had fallen in love:

[My friends] knew I wouldn't come out of the house, the house I drew with crayons, a house of primary colors I called love ... [they] tried to tell me it was not real. To prove them wrong, I drew a keyhole on the front door and invited them to look through to the other side. See for yourselves, I said. (Martínez 1994, 46)

María's use of the metaphor of a house illustrates her understanding of love as a domestic, private matter. Moreover, her offer to her friends indicates her concern with safety; notably, she does not invite her friends inside, but asks them only to observe through a "keyhole." María later critiques her own insistence on remaining "inside" and isolated by emphasizing the role of community in healing from trauma.

For his part, José Luis is not content with María's vision of him and continually attempts to correct her viewpoint, emphasizing that he is not unique and that he is only one of many. Early in the narrative, he shares with María poetry by Roque Dalton and Claribel Alegría. Such work, by an important member of the Salvadoran Communist Party and a leading resistance writer, respectively, speaks to a history of collective struggle. But María characteristically relates to the poetry only on an individual level: "all I could conclude was that his heart, in advance of his mind, was trying to make contact with me. Trying to say I love you through the subversive valentines of great poets" (Martínez 1994, 27). She has no concern for the legacy of revolution and resistance that comes through these poems; she can interpret them only for what they may mean for her own life.

Despite María's resistance, José Luis describes himself in relation to the community from which he came. When María opens José Luis's 
diary in the beginning of Part 2 of the novel, she finds that her lover, like Soledad, relies on plural subjects and pronouns:

Me and my compañeros were being shot at so we dived for cover. And when we were not dodging bullets, we were asking questions about who made and sold the bullets, who bought them, and why they always ended up in the hearts of poor people. We tried to figure these things out, to use our minds, our reason. Me and my seminary classmates are people of the book. (Martínez 1994, 51)

When José Luis begins his entry with the plural subject "me and my compañeros" he speaks of the plural targets of repressive state organs. According to America's Watch, the Salvadoran Army focused on social groups-unions, peasant leagues, community organizations, churches, schools, and political parties - that were seeking "a better existence within a political system dominated by a tiny oligarchy and its powerful military allies" (America's Watch 1991, 17). The tactics used by the military, paramilitaries, and death squads were meant to terrorize large segments of the population. "Murder, disappearance, arbitrary arrest, and torture ... served not only to eliminate political opponents but also to drive home the dangers of openly expressing dissent" (17). When he identifies himself as a member of an oppressed group and similarly aligns himself with an entire class of oppressed people ("the poor") José Luis speaks to this history. In addition, José Luis stresses the material basis of violence as he invokes trade and capital, asking who made the bullets, who sold them, and why they were used against the poor.

José Luis goes on to describe his activism in the United States in a way that reflects his adoption of a new, community-based identitythat of an immigrant. He writes in his diary about activism within both the sanctuary and immigrant communities: "speaking to the other dishwashers about their situation, or helping volunteers translate human rights alerts" (Martínez 1994, 52). In connecting immigrants and refugees, José Luis envisions a new kind of transnational citizen, what Chela Sandoval calls a "citizen-subject" (Sandoval 2000, 184). According to Sandoval, just as political leaders no longer represent individual nation-states but multinational interests, so too can "citizen-subjects ... become activists for a new decolonizing global terrain, a psychic terrain that can unite them with similarly positioned citizen subjects within 
and across national borders" (Sandoval 2000, 184). José Luis's discussions with other dishwashers recognize their similar positions vis-à-vis the world of global capital; although José Luis left El Salvador partly because of the presence of a military regime kept afloat by U.S. arms and capital, many immigrants leave their home countries owing to unstable economic situations exacerbated by U.S.-backed trade agreements. At the same time, José Luis does not lose sight of the specificity of the circumstances behind his exile, writing in his diary that thoughts of "friends sleeping under ceiba trees or ... in cement [cells]" keep him awake at night (Martínez 1994, 52). Thus, José Luis's understanding of himself in relation to transnational military and economic processes helps him to work with others who have emigrated in response to military and economic imperialism.

Although José Luis is able to understand himself as a Salvadoran in relation to other immigrants in the U.S., he remains unable to fully comprehend María's Chicana identity. He identifies her "belief that people can be made from scratch in the promised land" as "so American" and later conflates María with those responsible for the war in El Salvador (Martínez 1994, 52). After María reads an article about the rape and murder of several U.S. nuns in El Salvador, he tells María: "you don't know what it's like to suffer" (75). María remembers:

He saw in me an image of a gringa whose pale skin and tax dollars are putting his compatriots to death. My credentials, the fact that I am Mexican American, don't count now; in fact, they make things worse. . . Earlier in the morning he had made love to a Chicana. But after telling him the news of the nuns' deaths, I am transfigured. For a terrible disfigured moment, I am a yanqui, a murderess, a whore. (Martínez 1994, 75)

Although José Luis has indicted María on nationalist grounds, she interprets his anger as a comment on her sexuality, pointing to the ways in which issues of community-formation turn on female sexuality. For Chicana/os, the link between sexuality and community is nowhere more pronounced than in the figure of La Malinche, the indigenous woman who translated for the conqueror Hernán Cortes and whose name is synonymous with "whore."10 Although Chicana feminists have devoted several decades to re-interpreting $\mathrm{La}$ Malinche, Katherine Sugg argues that Chicana feminists and lesbian feminists in particular have somewhat ambivalently approached 
issues of female sexuality and its relationship to Chicana/o community. According to Sugg, authors such as Cherríe Moraga, Terri de la Peña, and Emma Pérez "variously re-inscribe and refuse the seductions of dominant political myths" by, for example, rewriting Malinche as a white woman (Sugg 2002, 167). With her focus on how women's bodies intersect with transnational processes and communities, Martínez offers a new way of thinking through these relationships. What neither José Luis nor María seems to notice is that the "us" in which José Luis claims membership is represented by the dead bodies of four U.S. church women. ${ }^{11}$ The bodies of these women, murdered by Salvadoran forces financed by U.S. money, highlight the inability of ethnic nationalism - whether Salvadoran or Chicana/o-to adequately account for the ways in which women's bodies are marked by transnational processes.

The narrative continuously highlights the intersection among women's bodies, violence, individuals, and communities. Soon after María and José Luis discuss the nuns' murder, María finds a poem in her lover's Bible. "Lamentation," credited to José Luis's murdered fiancé, Ana, offers a perspective on how violence enacted against individuals infects groups of people. The poem reads:

When at last my man

gets out

to become a new man

in North America,

when he finds a woman

to take the war out of him,

she will make love to a man

and a monster,

she will rise

from her bed,

grenades

ticking in her. (Martínez 1994, 82) ${ }^{12}$

In the violent, climactic scene of the novel, Ana's voice rings prophetic as José Luis transforms into a monster that beats his North American lover, María. The "grenades ticking" in María reveal themselves to be her own repressed memories of sexual abuse, and they in turn explode in the form of a flashback. In addition to its application to the lives of the novel's characters, "Lamentation" details the ways 
that violence enacted on individual bodies reverberates throughout communities. The narrator of the poem suggests that the brutal Salvadoran civil war, funded largely by the United States government, will in turn bring violence to U.S. soil. As the poem portrays, violence doesn't simply travel across national or geographic boundaries, but across physical ones, and even between individual bodies. Moreover, "Lamentation" suggests that sexual intimacy is a means through which violence can be transferred and transformed. The last two lines of the poem - "grenades / ticking in her" - point to the cyclical nature of violence. Just as the male lover's migration to the United States marks the U.S. as a site unable to sublimate violence, the imminent explosion marks the female body as only a temporary receptor of violence. By directing readers' attention to the ways that violence is disseminated and multiplied - the multiple grenades within the female lover's body will no doubt harm her, but also others - the poem asks us to understand violence, be it political, sexual, or emotional, as something that affects communities.

When "Lamentation" appears nearly two-thirds of the way through Mother Tongue, it signals a significant shift in the development of the story and its characters. Earlier sections of the novel describe how characters invoke or fail to invoke community-based identities. Although José Luis turns into a monster and transfers his war to María's body, the explosion that María experiences is not a physical one, but a psychological and communicative one. Here, then, Martínez offers an alternative to the perpetuation of violence. Although the novel narrates how violence directed at communities touches the bodies and lives of individuals, as I will discuss below, Mother Tongue also offers its own hopeful distortion of this process in which individuals become involved in community movements against violence.

\section{The only way to take the war out of a man is to end the war, all wars}

While José Luis and María misrecognize each other in relation to their ethnic and national communities, Soledad provides a model for connecting across difference. Soledad successfully explains the relation of the global to the local and of the community to the individual. Although she figures herself as a member of a transnational community, she accounts for differences in language and citizenship 
and moreover employs difference as a more effective means of activism. When Soledad sees that María is falling in love, she recognizes both the risks inherent in loving a survivor of war, as well as the futility of changing María's heart. She recounts her own relationship with a refugee- "My Carlos was a good man but the war made him loco sometimes" - and then offers her understanding of war and love: "No, no, the only way to take the war out of a man is to end the war, all wars" (Martínez 1994, 70). From Soledad's perspective, she cannot effect change in her own life and the lives of her loved ones without a global vision.

Whereas María thinks that she can take the war out of a man through love and sex, Soledad proposes that love on a larger scaleending all wars - is the only way to truly love a man. María tells readers of Soledad's vision of political love: "At first even I was fooled; I though she had married for love. And in a sense, she had. Having no children of her own, she adopted El Salvador. She knew its provinces, its disappearances" (Martínez 1994, 71). Though Soledad "adopts" El Salvador, she does not do so in a paternalistic way. Her love for El Salvador comes through knowledge, activism, and the recognition of difference. When she tells María of her ex-husband Carlos, she mentions the way war made him "loco," stressing her sympathetic distance from his experiences, and though she says of El Salvador, "I know, I've been there," she uses her firsthand knowledge to stress the individual nature of the experiences of war- "You can't even hear yourself think in El Salvador" (70). Although Soledad "knows" El Salvador- "its provinces, its disappearances" - she doesn't claim to know the experiences of all its refugees, and she acknowledges that men such as Carlos have undergone things she can't understand.

María's descriptions of Soledad and the advice of her madrina serve as evidence to both María and her readers that she has undergone radical change. Soledad's letters and her voice interspersed throughout the narrative suggest what nineteen-year-old María had not yet learned and what thirty-nine-year old María has come to understand. In addition to Soledad's advice about ending all wars, María herself drops hints that a renewed understanding of community was key to her personal growth. In a passage written later in life, María suggests that what was missing in her youth was an understanding of her connection to the lives of people around her. Speaking of her current relationship, she speaks of "real love" and tells her readers that her lover's stories "exor- 
cise the inner authorities that say quiet, don't tell, that keep women like me from speaking the truth about their lives" (Martínez 1994, 58). Here, María's idea of "real love" is tied to others, especially other women. Whereas once her concept of love had been to draw a house around herself and her lover and invite her friends to look inside, now she displays her willingness and ability to step outside her own house and make connections with others. What is most significant about this passage, however, is that María connects "real love" and "truth" to "stories," "women like me," and "their lives" (58). María's concept of truth, this passage illustrates, stems not from a singular experience, but from a collective act of storytelling.

Mother Tongue's difficult climactic scene, in which José Luis beats María, disturbingly melds violence and redemption. Although the novel's dominant themes-war, sex, violence, voice, and memory-play important roles, community identification propels the healing in which both characters subsequently participate. Through the violence that she suffers at his hands, María relates both her lover and herself to the communities that were so missing in their lives. Whereas once she was unable to identify his features as possessing the markers of one nation or ethnicity, when José Luis lapses into a trance, María sees his country and his history for the first time: "And in his eyes I could see people running and dropping, flames and plumes of smoke, processions of women holding photographs of their children, telephone poles falling, bridges flying to pieces" (Martínez 1994, 100). María does not see an individual portrait of grief, nor the tragedy of one woman or man; rather she sees the destruction of an entire community. What had been missing in her understanding of José Luis was not knowledge of his individual experiences - though she refused to assimilate this knowledge-but a recognition of the communal nature of suffering, of the links between his own experiences and those of his compatriots. This scene indicates María's newfound ability to connect what she sees in José Luis's eyes to his experiences. She tells her son, "Your father and his friends had handed their lives over to the cause of stopping the war and in the end, they could not even flee from it" (100). She understands now that war is not something that she can take out of a/her man, but something that ravages entire communities and that can only be confronted on a large scale.

Soon after, María lapses into her memories of the abuse she suffered at the hands of a neighbor. In her narrative, she further develops her 
earlier connections between "truth" and "others" by scripting her tragedy in a way that talks not only of her own suffering, but the suffering of entire communities. Lomas notes that when María is abused while her neighbor watches scenes from the Vietnam War on television, the narrative creates a "crucial nexus between foreign and domestic violence" (Lomas 2005, 367). Lomas continues: "María's seven-year-old body figures as the country being invaded" (367). Whereas for Lomas this scene "underscores the accumulation of unresolved, incompletely articulated trauma from the U.S.-Mexico war through the neocolonial wars of the 1970s" (368), I would like to suggest that what is most powerful is the linking of María's war with José Luis's war and wars around the world. María is able to link her own abuse with the abuse of others, and she stresses this link when she tells her story to her son. According to María, her abuser goes on to "cancel whole populations" (Martínez 1994,104). The abuser is not someone who harms only her, but entire peoples. María emphasizes this to her son, she tells him: "you are not unique ... [you are] one of millions conceived in love and war" (101). She wants her son to understand what she herself understands, that we are linked to the lives of those around us and that if we want to improve our own lives, we must improve the lives of others, or, as Soledad says, to take the war out of a man, we must end all wars.

Although María's ability to see her own trauma is tied to her ability to see José Luis's trauma, and vice versa, what she "sees" when she encounters her experiences and José Luis's is the connection between her lover and others. That is, she doesn't suddenly understand José Luis's history of torture; rather, she sees a community that is still suffering from trauma, and then she is able to understand the relationship of José Luis to this community. Likewise, she doesn't simply remember her abuse as it happened to her, she remembers it in a way that connects her abuser to someone who goes out to "cancel whole populations" (Martínez 1994, 104). María connects the abuse that she suffered to "children everywhere crying out" and even brings this experience to her son/her reader when she switches to the second person to say, "a knife in a place for which you have no word is the most lethal of weapons. It carves words on your inner walls to fill the void" (103). María takes what she sees in José Luis's eyes-a community being destroyed-in order to understand the man who is part of that community; she then takes her own memories of abuse and links them to the abuse of others-of Vietnamese campesinos, of survivors of domes- 
tic violence, and finally to "you," or us, her readers. The relationship between self and community is used to understand both individuals and groups, and furthermore, to make connections to groups, to connect us/you to her/them.

After their violent confrontation, the characters turn to their respective communities to move toward healing. The first voice we hear once María has recounted her story is, significantly, Soledad's. Soledad shares her own history of sexual abuse - "it happened to me too" and then tells María "you're not alone" (Martínez 1994, 105). Soledad goes on to highlight the structural nature of inequality and to connect her and María's experiences to an even larger community of women. Though she somewhat cynically says, "I'm beginning to believe all those ladies who carry on about 'the patriarchy,"' she nevertheless highlights patriarchy as a source of structural inequality and furthermore suggests that neither she nor María are alone, but are joined by "all those ladies" (105). Also in this letter, Soledad offers her take on María's early metaphor of the house. She tells her goddaughter: "Life is a risky business but the alternative is to dig a hole and bury yourself. You may not know it, but I have my share of scars. And I would have them even if I had never come out of the house. Better to have scars from living than from hiding" (106). Here, Soledad refers to the fact that for so many women, the home is no safe space. Indeed, María's abuse took place in her own house. She also suggests that healing cannot wholly take place within the private, domestic space. Soledad's suggestion is echoed in José Luis's subsequent absence from the narrative. By removing José Luis from María's life, Martínez indicts him as an abuser; there can be no future between María and José Luis. At the same time, individual solitude-for either character-is not the solution; rather they must seek healing with/through others.

María and José Luis begin to heal from their respective traumas in ways that closely align each character with other members of their communities. María writes that as part of his process of recovery José Luis "let himself cry ... about Ana ... and about all his friends" (Martínez 1994, 107). José Luis expresses his grief not only for his own lost life, but for the lost lives of his friends and lovers. In addition, José Luis begins to seek help from people who have experienced similar traumas. $\mathrm{He}$ begins to see a doctor whose parents were survivors of concentration camps. José Luis is strengthened by his ability to converse with others, and he eventually becomes active in a community of survivors of tor- 
ture, joining a delegation to the Toronto Center for War Survivors. By connecting his healing to that of members of similar communities, José Luis reflects the support that was missing from his life and suggests a model for collective healing.

María, too, becomes active in community-based issues. Readers see María reflected through the eyes of her son, José Luis Jr., and his perspective on his mother's transformation proposes that justice, like violence and trauma, may be a communal project. Mother and son visit San Salvador, and after reading of efforts by the Church to open mass graves, José Luis says: "It sounds like they won't rest until everyone is accounted for" (Martínez 1994, 112). Here once again Soledad's admonition about how to take the war out of one man echoes in José Luis Jr.'s words-in order to account for the deaths of just one person, all people must be accounted for. José Luis Jr. also describes how María connects with other women in El Salvador. The young Chicana who had nearly no family or friends and whose Spanish was "like an old car, parts missing" now chats with Sister Margarita like they "were old friends" and later talks in Spanish to two Salvadoran women who have also lost children $(7,112)$. Whereas María once shunned connections to others, both she and her son now seem to recognize that she belongs among the mothers of the disappeared.

María's activism echoes calls by U.S. feminists of color to recognize the relationship among communities of color within the U.S., U.S. foreign and domestic policies, and post-colonial and liberation movements. In her preface to the 2001 edition of This Bridge Called My Back: Writings By Radical Women of Color, Cherríe Moraga calls on U.S. women of color to assume "a position of a global women of color activism, while at the same time remaining specific to our concerns as Native, Asian, and African-originated women living within specific nation-states" (Moraga and Anzaldúa 2001, xvii). Moraga acknowledges the "deep ambivalence" women of color may feel about issues of nationalism, considering "rape perpetuated in the name of the nation," and ethnic and cultural nationalist movements that "silenced and severely castigated women's freedom of movement and expression" (xxvi). By scripting María as a character whose recognition of her own experiences of domestic violence enable her to hear the voices of Salvadoran survivors, and by emphasizing the transformative effects María's trip to El Salvador has on her growth as a woman and an activist, Martínez offers an example of how confronting gen- 
dered violence within the nation-state (the U.S. and El Salvador), may play an important role in mounting anti-imperial resistance to many kinds of violence.

Importantly, María illustrates her understanding of historical and national specificity through an altar she builds in her house and via the activism in which she participates. After they return from El Salvador, María and José Luis Jr. place a poster of the Madre de los desaparecidos alongside a picture of José Luis and a picture of María as a seven-yearold girl. María's altar lies within her home, the same space in which her abuse took place; but rather than reclaiming only this space, María becomes involved in local activism, echoing Soledad's admonishment to "leave the house." She thus reclaims the domestic sphere in the service of a global project. ${ }^{13}$ Moreover, María incorporates her multiple identities-as a mother, a Chicana, a survivor of sexual abuse, and a U.S. citizen -in her social-justice work. Leveraging her status as a U.S. citizen, María participates in a letter-writing campaign, asking the Salvadoran government to allow forensic experts to document the extent of the war's atrocities. Thus, community-based activism becomes a way to link individual experiences of trauma to one another in a transnational struggle to end violence and impunity.

\section{we come / to truth together / or not at al1 ${ }^{14}$}

The structure of Mother Tongue and its opening and closing pages suggest a community-based approach to storytelling. An excerpt from the Popol Vuh, the book of creation of the Mayan/K'iché appears before María's narrative opens:

Remember us after we are gone. Don't forget us. Conjure up our faces and our words. Our image will be as a tear in the hearts of those who want to remember us.

This quote contains plural referents ("we," "us," "our") only, emphasizing the story of not one person, but an entire group. The use of these pronouns also implies that a story is the story of an entire group; Martínez affirms this sentiment when in her acknowledgments she says "It takes more than one person to tell a story." As María and Martínez rely on multiple narrators to tell their stories, they reinforce the idea that stories are not just individual narratives but narratives of groups 
of people, of communities, and that storytelling requires groups of people. Finally, the novel ends with a letter from José Luis. The letter's appearance as an "Epilogue" after María has finished telling her story means that readers remain unsure whether María herself ever received or read the letter. This choice by Martínez is a final example of the author's attempt to create a community response. With José Luis's letters in our hands, it remains up to us to act on the demands for justice of which he is a part.

In a discussion of testimonio as a democratizing force, John Beverley affirms the connection between cultural production and community-formation. He writes that testimonio is "directed not only toward the memorialization of the past but also to the constitution of more heterogeneous, diverse, egalitarian, and democratic nation-states, as well as forms of community, solidarity, and affinity that extend beyond or between nation-states" (Beverley 2004, 24). Thus, forms of writing that rely on communities, such as testimonio, are themselves implicated in the attempt to create new, democratic communities. Martínez and María affirm the ability of storytelling to create communities and affirm solidarity beyond the level of the nation-state. When Martínez constructs a narrative that reflects a transnational community, and one that, moreover, relies on characters writing from the perspective of or within several different nation-states, she echoes this relationship between narrative and community while simultaneously suggesting that narrative has the ability not only to reflect communities, but to create them. Her characters exhibit transnational solidarity and invite readers to join in this community.

As the epigraph from Harold Pinter's Nobel Prize acceptance speech that opens this article reminds us, the frank recognition of the history of U.S. intervention in Central America is integral in creating a historical narrative that is marked by transparency and justice. This recognition must involve attention to the continuities and discontinuities between survivors of violence and the effects of difference owing to race, gender, sexuality, and nationality. When María uses her understanding of herself as a survivor of domestic violence to become a transnational activist, a woman working within the United States but with a global vision, she illustrates how the experiences of the individual may be leveraged in a quest for communal justice. At the same time, with its highlighting of the role of collective storytelling, Martínez's novel affirms the power of narrative itself. 
Finally, a poem attributed to José Luis provides a truly transnational picture of bodies engaged in healing:

my rib throbs beneath

your palm, the rib

they fractured with

a rifle, the rib

that if taken into

the body of america

might make it new (Martínez 1994, 80)

In this poem, the perpetrators of violence-"they" - are placed in opposition to "us" - a couple that is joined by flesh against flesh. The resulting image references the multiple targets of violence while it affirms a vision of united resistance. At the same time, the two bodies are not collapsed into one; what will result from this new union, we are promised, will not be simply the reconstruction of what was, but something wholly unprecedented. In the story of Genesis, God takes Adam's rib to make Eve, but in this poem a couple unmarked by gender together heals the fractured body part to create something entirely "new." Radical hope and uncertainty join together in a distinctly transnational space. While "Lamentation" referred to "North America," this untitled poem refers to "america" as "one body," erasing national divides and affirming the interconnectedness of all of las américas. Both this poem and the novel recognize the lingering effects of the history of U.S. intervention in El Salvador and tragically detail the ways in which military and political violence cross national boundaries to intersect with issues of race, gender, identity, and sexuality. At the same time, both works detail the extent to which processes involving healing and the search for justice may similarly be polyvocal, multifaceted, and transnational in scope.

\section{Notes}

1. See Pearce 1982 and LeoGrande 1998 for more on U.S intervention in Central America and El Salvador.

2. The FMLN, or Farabundo Martí National Liberation Front, was a coalition of five guerrilla organizations that joined together in armed resistance to the government in 1980. Following the signing of the Peace Accords in 1992, the FMLN became a political party. 
3. I use the term "transnational" precisely because of the word's links to "both progressive and hegemonic phenomena" (Black 2004, 228). That is, "transnational" foregrounds economic processes (embodied in transnational corporations and the agreements that benefit them) and the importance of nationstates in both revolutionary and reactionary movements.

4. From "North American Woman's Lament (for Orlando)" in Gaspar de Alba, Herrera-Sobek, and Martínez 1989.

5. Although I share Young's suspicion of a rhetoric of community that is deployed uncritically, my analysis of the relationship between the politics of difference and the politics of community diverges from hers. Young argues for a "politics of difference" as an ideal way to develop a model of "social relations without domination in which persons live together in relations of mediation among strangers with whom they are not in community" (Weiss and Friedman 1995, 234), whereas I point out that community in Mother Tongue is essential for the recognition of difference and thus a politics of difference and a politics of community need not be antithetical ideas.

6. Alegría's name is a pseudonym he uses to conceal his identity; earlier he uses "A. Romero" as homage to Archbishop Oscar A. Romero, who was gunned down while saying Mass in San Salvador on March 24, 1980.

7. The sanctuary movement arose out of church-based activism to prevent the deportation of Central American refugees, whose status as political refugees was not recognized by the Reagan administration. By the mid-1980s, when Mother Tongue takes place, the movement had grown to include almost 400 churches, synagogues, universities, and cities. Governor Toney Anaya declared Martínez's home state of New Mexico a sanctuary in 1986 (Cunningham 1995, 65).

8. See Castillo 1997 and Lomas 2006 for a discussion of voice; Lyon-Johnson 2005 and Lomas 2006 for a discussion of the body; and Kandiyoti 2004 and Caminero-Santangelo 2007 for a discussion of cross-cultural relations and solidarity in the novel.

9. For example, at their first encounter, she sees his face as Olmec, an indigenous group that, as Debra Castillo points out, has nothing to do with El Salvador (Castillo 1997, 12). Later, she chooses not to listen when he gives his testimony to a group of church people and mistakes his scars from torture as marks from a lover's hands (Martínez 1994, 18, 81).

10. See Alarcón 1981.

11. The women, who in Mother Tongue are identified as Eve O'Conner and María Quinto of San Antonio, TX (Martínez 1994, 73) are a reference to Sister Dorothy Kazel, Sister Ita Ford, Sister Maura Clarke, and Jean Donovan who were abducted, raped, and murdered in December 1980.

12. What appears as "Lamentation" in Mother Tongue is one stanza from a poem published by Martínez in 1989 titled "Prologue: Salvadoran Woman's Lament" in Gaspar de Alba, Herrera-Sobek, and Martínez 1989. This frequent cross-referencing of her own work is a trademark of Martínez, who has published on similar themes - violence, language, U.S. imperialism, Chi- 
cana identity -in a variety of formats: novels, essays, newspaper articles, and poetry.

13. Penny Weiss writes: "Both feminist communities and activism rooted in women's traditional roles, relations, and networks blur the distinction between public and private and, related to that, upset the easy association of the private with the female and the public with the male" (Weiss and Friedman 1995, 16).

14. From "Bare Necessities" in Gaspar de Alba, Herrera-Sobek, and Martínez 1989.

\section{Works Cited}

Alarcón, Norma. 1981. “Chicana's Feminist Literature: A Re-vision through Malintzin/ or Malintzin: Putting Flesh Back on Object." In This Bridge Called My Back: Writings By Radical Women of Color, edited by Cherríe Moraga and Gloria Anzaldúa. Watertown, MA: Persephone Press.

Americas Watch. 1991. El Salvador's Decade of Terror: Human Rights since the Assassination of Archbishop Romero. New Haven and London: Yale University Press.

Beverley, John. 2004. Testimonio: On the Politics of Truth. Minneapolis: University of Minnesota Press.

Black, Shameem. 2004. “Fertile Cosmofeminism: Ruth L. Ozeki and Transnational Reproduction." Meridians: feminism, race, transnationalism 5, no.1: 226-56.

Caminero-Santangelo, Marta. 2007. On Latinidad: U.S. Latino Literature and the Construction of Ethnicity. Gainesville, FL: University Press of Florida.

Castillo, Debra. 1997. “Barbed-Wire Words: Demetria Martínez' Mother Tongue." Intertexts (Spring): 8-24.

Cunningham, Hilary. 1995. God and Caesar at the Rio Grande: Sanctuary and the Politics of Religion. Minneapolis and London: University of Minnesota Press.

Gago, Veronica. 2997. "Dangerous Liaisons: Latin American Feminists and the Left." NACLA Report on the Americas 40, no. 2: 17-19.

Gaspar de Alba, Alicia, María Herrera-Sobek, and Demetria Martínez. 1989. Three Times a Woman. Tempe, AZ: Bilingual Press/Review.

Gutiérrez y Muhs, Gabriella Favela. 2004. “Subjectifying Entities/Emerging Subjectivities in Chicana Literature through the Literary Production of Demetria Martínez and Norma Elia Cantú: Madres, Comadres, Madrinas, Niñas Madres, Tías, Abuelas y Solteronas." Ph.D. diss., Stanford University.

Hitt, Jack. 2006. "Pro-Life Nation." The New York Times http://www.nytimes. com/2006/04/09/magazine/09abortion.html (accessed April 4, 2009).

Kandiyoti, Dalia. 2004. "Host and Guest in the 'Latino Contact Zone': Narrating Solidarity and Hospitality in Mother Tongue." Comparative American Studies 2, no. 4: 421-46. 
LeoGrande, William M. 1998. Our Own Backyard: The United States in Central America, 1977-1992. Chapel Hill: University of North Carolina Press.

Lomas, Laura. 2006. “The War Cut Out My Tongue': Domestic Violence, Foreign Wars, and Translation in Demetria Martínez." American Literature 78 (June): 357-87.

Lovato, Roberto. 2009. “Leftist FMLN Candidate Mauricio Funes Wins El Salvador Presidential Election, Ending Two Decades of Conservative Rule." Democracy Now! http://www.democracynow.org/2009/3/16 (accessed April 4, 2009).

Lyon-Johnson, Kelli. 2005. "Acts of War, Acts of Memory: 'Dead-Body Politics' in US Latina Novels of the Salvadoran Civil War." Latino Studies 3: 205-25.

Martínez, Demetria. 1994. Mother Tongue. Tempe, AZ: Bilingual Press/Editorial Bilingüe.

Mohanty, Chandra Talpade. 2003. Feminism without Borders: Decolonizing Theory, Practicing Solidarity. Durham, NC, and London: Duke University Press.

Moraga, Cherríe, and Gloria Anzaldúa, eds. 2001. This Bridge Called My Back: Writing by Radical Women of Color. Berkeley, CA: Third Woman Press.

Pearce, Jenny. 1982. Under the Eagle: U.S. Intervention in Central America and the Caribbean. London: Latin American Bureau.

Pinter, Harold. 2005. "Art, Truth and Politics." Nobel Lecture. http://nobelprize. org/nobel_prizes/literature/laureates/2005/pinter-lecture-e.html (accessed May 6, 2008).

Richard, Nelly. 2004. Masculine/Feminine: Practices of Difference(s). Durham, NC, and London: Duke University Press.

Richards, Constance S. 2000. On the Winds and Waves of Imagination: Transnational Feminism and Literature. New York and London: Garland Publishing.

Sandoval, Chela. 2000. Methodology of the Oppressed. Minneapolis: University of Minnesota Press.

Sugg, Katherine. 2002. "The Ultimate Rebellion: Chicana Narratives of Sexuality and Community." Meridians: feminism, race, transationalism 3, no. 2: 139-70.

Weiss, Penny A., and Marilyn Friedman. 1995. Feminism and Community. Philadelphia: Temple University Press.

Wyatt, Jean. 2004. Risking Difference: Identification, Race, and Community in Contemporary Fiction and Feminism. Albany: State University of New York Press.

Young, Iris Marion. 1990. Justice and the Politics of Difference. Princeton: Princeton University Press.

\section{$\ddagger \ddagger \ddagger \ddagger$}

Ariana Vigil is an assistant professor of English and Ethnic Studies at the University of Nebraska-Lincoln. She conducts teaching and research on contemporary U.S. Latina/o literature and is currently working on a book that looks at Latina/o responses to U.S. intervention. 